\title{
Immunotherapy for patients with acute myeloid leukemia using autologous dendritic cells generated from leukemic blasts
}

\author{
LI LI $^{1 *}$, KRZYSZTOF GIANNOPOULOS ${ }^{1,4^{*}}$, PETER REINHARDT ${ }^{2}$, \\ JACEK TABARKIEWICZ ${ }^{4}$, ANITA SCHMITT ${ }^{2}$, JOCHEN GREINER ${ }^{1}$, JACEK ROLINSKI $^{4}$, \\ IWONA HUS ${ }^{3}$, ANNA DMOSZYNSKA ${ }^{3}$, MARKUS WIESNETH ${ }^{2}$ and MICHAEL SCHMITT ${ }^{1}$
}

${ }^{1}$ Department of Internal Medicine III, University of Ulm; ${ }^{2}$ Institute for Clinical Transfusion Medicine and Immunogenetics, Ulm, Germany; Departments of ${ }^{3}$ Hematooncology and ${ }^{4}$ Clinical Immunology, Medical University of Lublin, Lublin, Poland

Received October 20,2005; Accepted December 2, 2005

\begin{abstract}
Vaccination with dendritic cells (DCs) as professional antigen presenting cells generated from autologous leukemic blasts might elicit anti-leukemic T cell responses in patients with acute myeloid leukemia (AML). To test this hypothesis, autologous AML-DC were generated under good manu-facturing practice (GMP) conditions and injected s.c. into five AML patients up to four times at a biweekly interval. No severe adverse side effects were observed. Three patients remained in a stable condition for 5.5-13 months and two patients died from rapidly progressive AML. Compared to the initial T cell frequency, enzyme linked immunosorbent spot (ELISPOT) assays revealed a significant increase of granzyme $\mathrm{B}$ releasing $\mathrm{CD} 8^{+} \mathrm{T}$ cells specifically recognizing the PRAME derived peptide (ALYVDSLFFL), a leukemia associated antigen expressed by AML blasts. The cytokine levels in the serum of vaccination AML patients as assessed by cytokine bead assay changed over the period of vaccination to an elevated type $1 \mathrm{~T}$ helper cell pattern. Interferon $\gamma$ production by $\mathrm{CD}^{+} \mathrm{T}$ helper cells increased during vaccination. In summary, we demonstrated that autologous AML-DC vaccination is well tolerated and can result in an enhanced and specific response of cytotoxic T cells in AML patients.
\end{abstract}

\section{Introduction}

Acute myeloid leukemia (AML) is a hematological disease characterized by the clonal proliferation of undifferentiated

Correspondence to: Dr Michael Schmitt, Department of Internal Medicine III, University of Ulm, Robert-Koch-Str. 8, D-89081 Ulm, Germany

E-mail: michael.schmitt@uniklinik-ulm.de

${ }^{*}$ Contributed equally

Key words: acute myeloid leukemia, dendritic cells, leukemiaassociated antigen myeloid progenitor cells. The prognosis for AML patients is rather poor with a overall survival of $20-25 \%$ depending on the individual risk profile (1). In a fervent need for novel treatment modalities, immunotherapies might constitute a therapeutic option in addition to chemotherapy.

A new hope for efficient immunotherapeutic approaches has emerged after the characterization of dendritic cells (DCs) as the most professional antigen presenting cells with a unique property to prime naive T cells (2). DCs are considered to be important elements also in the induction of specific anti-tumor immune responses, as they have a unique capacity to activate a broad range of immune effector cells including T cells, B cells, NKT cells and NK cells $(2,3)$.

Recently, we have reported on the administration of tumor cell lysate or apoptotic body loaded DCs to B-cell chronic lymphocytic leukemia patients that led to immunological and even clinical responses (4). Several groups showed that DCs can be generated from the leukemic blasts of patients with AML or CML $(5,6)$. Choudhury et al $(7)$ and our group $(8,9)$ demonstrated that such autologous AML-DCs can stimulate anti-leukemic $\mathrm{T}$ cell responses. At present, leukemia is the only known malignancy in which DCs can be generated directly from the cancer cells. AML-DCs constitutively express tumor/leukemia associated antigens (TAA/LAA) such as the antigen preferentially expressed in melanoma (PRAME) (10), the Wilms tumor gene 1 (WT-1) (11) or the receptor for hyaluronic acid mediated motility (RHAMM/CD168) (8). Vaccination with AML-DCs has been suggested as a novel treatment option for AML patients by others (12-16). We report here on the clinical and immunological results of the first clinical vaccination trial with AML-DCs.

\section{Materials and methods}

Cell samples. Three patients were treated at the University Hospital of Ulm (Germany) and two patients at the Medical University of Lublin (Poland) in the framework of our AML-DC vaccination protocol approved by the local ethics committees. Informed consent was obtained from all patients. All patients were treated with AML-DCs second or third line in a palliative setting. The clinical characteristics of the patients in this study are summarized in Table I. 
Table I. Clinical characteristics of patients.

\begin{tabular}{lccccccc}
\hline & & & & & \multicolumn{2}{c}{ WBC (G/L) } \\
Patient no. & Initials & Age (years) & Sex & FAB type & Before & After & No. of DC vaccinations \\
\hline 1 & S.S. & 71 & M & M2 & 1.9 & 4.9 & 4 \\
2 & M.R. & 71 & F & M0 & 29.5 & NA $^{\text {a }}$ & 1 \\
3 & T.L. & 67 & M & Sec AML & 6 & NA $^{\text {a }}$ & 1 \\
4 & L.H. & 70 & F & M2 & 2.7 & 1.2 & 4 \\
5 & B.K. & 54 & F & M4 & 3.1 & 2.4 & 4
\end{tabular}

${ }^{a} \mathrm{NA}$, not available, as the patient died after the first vaccination. Sec AML, secondary AML from myelodysplastic syndrome (MDS). FAB type, type of AML according to the French-American-British classification. Before/after, before/after four vaccinations with AML-DC.

Culture of cell lines. Human cell lines were cultured in a standard medium consisting of RPMI-1640 (Biochrom, Berlin, Germany) supplemented with $10 \%$ (v/v) AB serum, $2 \mathrm{mM}$ L-glutamine, 100 units/ml penicillin and 100 units $/ \mathrm{ml}$ streptomycin. T2 cells and the K562 cell line were obtained from the 'Deutsche Sammlung von Zellen und Mikroorganismen' (DSZM, Braunschweig, Germany).

Cell isolation. Peripheral blood mononuclear cells (PBMCs) were isolated by Ficoll density gradient centrifugation. The viability of obtained PBMCs was always $>95 \%$, as determined by trypan blue staining. The viable cells were quantified in a Neubauer chamber (Zeiss, Oberkochen, Germany) and stored for RNA preparation and flow cytometric analysis in liquid nitrogen.

$m R N A$ preparation, reverse transcription and reverse transcriptase polymerase chain reaction $(R T-P C R)$. For the isolation of mRNA from the peripheral blood mononuclear cells (PBMC) isolated by Ficoll density gradient centrifugation, the $\mu \mathrm{MACS}$ mRNA isolation kit (Miltenyi Biotec, Bergisch Gladbach, Germany) was used according to the manufacturer's instructions. Fifty ng of mRNA was reverse transcribed into $20 \mu \mathrm{l}$ of cDNA using a First Strand cDNA synthesis kit for RT-PCR (AMV) (Roche Diagnostics, Mannheim, Germany). The expression of PRAME was determined as described previously (8).

Generation of AML-DCs. Patients underwent a single 3-h leukapheresis using a COBE Spectra cell separator (Gambro, Lakewood, USA), 5 to $70.8 \times 10^{9}$ peripheral blood mononuclear cells (PBMC) were harvested. DCs were generated from leukapheresis products and cryopreserved as previously described $(8,9)$. Cells were seeded $\left(1 \times 10^{6}\right.$ cells $\left./ \mathrm{cm}^{2}\right)$ into culture flasks (Nunc, Roslild, Denmark) in RPMI-1640 medium (Biochrom AG, Berlin, Germany) supplemented with 2\% human $\mathrm{AB}$ serum (German Red Cross Blood Center, Ulm, Germany), $2 \mathrm{mM}$ L-glutamine, 100 units/ml penicillin and 100 units $/ \mathrm{ml}$ streptomycin. After $2 \mathrm{~h}$ of incubation at $37^{\circ} \mathrm{C}$, non-adherent cells were removed and adherent blood monocytes (purity $>80 \%$ of $\mathrm{CD} 14^{+}$cells by FACS analysis) were cultured in RPMI-1640 medium supplemented with $100 \mathrm{ng} / \mathrm{ml}$ human granulocyte-macrophage colony stimulating factor (GM-CSF, Leukomax, Novartis, Basel, Switzerland),
1,000 IU/ml interleukin-4 (Strathmann, Hannover, Germany) and $10 \%$ human AB serum. For maturation of the cells, a complete medium change was performed on day 6 . The new medium contained GM-CSF and IL-4 in the concentrations mentioned above and additionally $50 \mathrm{ng} / \mathrm{ml} \mathrm{TNF- \alpha} \mathrm{(Strath-}$ mann). The AML-DC cultures were fed with fresh medium and cytokines every three days and cell differentiation was monitored using inverse light microscopy. The expression of cell surface molecules on the DCs was analyzed using flow cytometry after 8 days of culture.

Cell viability and morphologic studies. The viability of the DCs harvested after 8 days of culture was assessed by trypan blue staining using a Neubauer counting chamber, and the morphology of the cells was analyzed by light microscopy. For light microscopy, DC suspensions were spinned and stained with May-Gruenewald solution (Merck, Darmstadt, Germany).

Immunophenotyping of the cells. Harvested cells were washed in FACS medium [phosphate-buffered saline (PBS) containing $1 \%$ bovine serum albumin (BSA)] and stained at $4{ }^{\circ} \mathrm{C}$ for $20 \mathrm{~min}$ by antibodies directly conjugated with Fluorescein isothiocyanate (FITC) or phycoerythrin (PE). Thereafter, cells were washed three times with PBS and analyzed by FACScan (Becton-Dickinson, Heidelberg, Germany) using CellQuest $^{\mathrm{TM}}$ software (Becton-Dickinson). Antibodies were the following: FITC-labeled anti-mouse IgG, anti-human HLA-DR, CD40 and CD83, as well as PE-labeled anti-mouse IgG, antihuman HLA-ABC, CD80 and CD86 (Becton-Dickinson).

Vaccination protocol. Eligible patients received up to 4 injections with $5 \times 10^{6}$ AML-DCs at a biweekly interval. The vaccine was administered s.c. in the vicinity of the inguinal lymph nodes. The treatment schedule is displayed in Fig. 1. Clinical examination, hematological blood testing and immunological screening were performed before each vaccination.

Assessment of intracellular interferon gamma $(I F N-\gamma)$. The expression of intracellular IFN- $\gamma$ by CD4 and CD8 positive cells was assessed by three color flow-cytometry. PBMC were stained with anti-CD ${ }^{*} \mathrm{PE}$ and anti-CD $8 *$ peridinin chlorophyll protein (PerCP) moAbs (Becton-Dickinson). Following membrane staining, the cells were fixed and permeabilized according to the manufacturer's protocol using 
the IntraStain kit (DakoCytomation, Glostrup, Denmark) and simultaneously stained with anti-IFN- $\gamma$ FITC-labeled moAbs (Becton-Dickinson). Thereafter, the cells were washed twice, acquired using a FACScan flow cytometer and analyzed using CellQuest software. Relevant mouse isotype controls were used for every experiment. At least 10,000 events gated on lymphocytes were collected.

Assessment of cytokine concentrations. The serum level of IL-2, IL-4, IL-5, IL-10, tumor necrosis factor- $\alpha$ (TNF- $\alpha$ ) and IFN- $\gamma$ in the PB was measured by the human Th1/Th2 cytokine cytometric bead array (CBA) (Becton-Dickinson) using a FACScan flow cytometer equipped with CellQuest software (Becton-Dickinson). The patients' plasma samples were frozen and stored at $-192^{\circ} \mathrm{C}$ in liquid nitrogen. Immediately before the experiments, samples were thawed and assessed for the concentration of cytokines according to the manufacturer's protocol.

Mixed lymphocyte peptide culture (MLPC) and IFN- $\gamma$ and granzyme B ELISPOT assays. PBMCs from AML patients were separated by Ficoll and subsequently selected by CD8 magnetic beads through a MACS column (Miltenyi Biotec). Eight days of mixed lymphocyte peptide culture (MLPC) with PRAME- (pos. 300-309: ALYVDSLFFL) and IMP-derived peptides (pos. 58-66: GILGFVFTL) were followed by granzyme B ELISPOT assays as described previously $(9,17)$.

\section{Results}

Quality control of the vaccine preparations. AML blasts were obtained by leukapheresis. After eight days of DC culture as described in Materials and methods, floating and semi-adherent

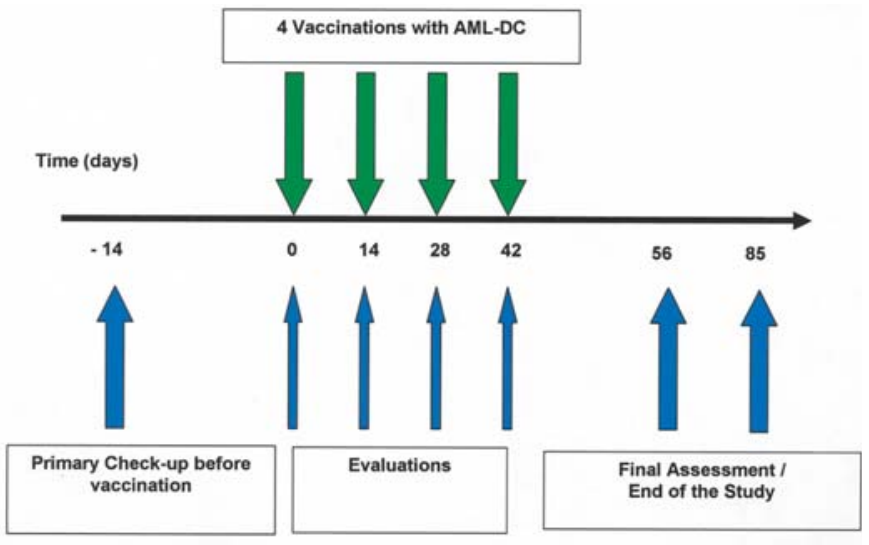

Figure 1. Schedule of clinical vaccinations with AML-DCs. Patients received up to 4 injections with $5 \times 10^{6}$ AML-DCs at a biweekly interval. The AMLDCs were administered s.c. in the vicinity of inguinal lymph nodes. Blood samples were taken before every vaccination and on days +56 and +85 .
A

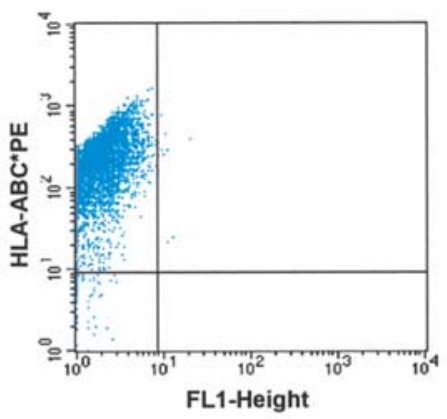

C

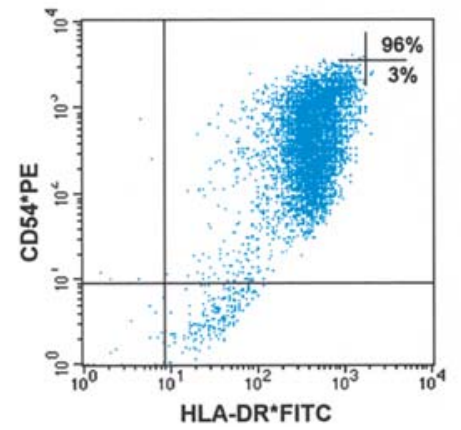

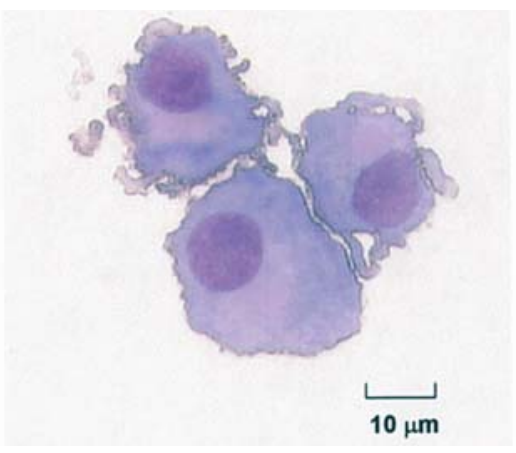

Figure 2. DCs generated from AML blasts visualized by light microscopy. DCs generated from AML blasts and visualized by light microscopy (x400) display typical dendritic veils and excentric nuclei.
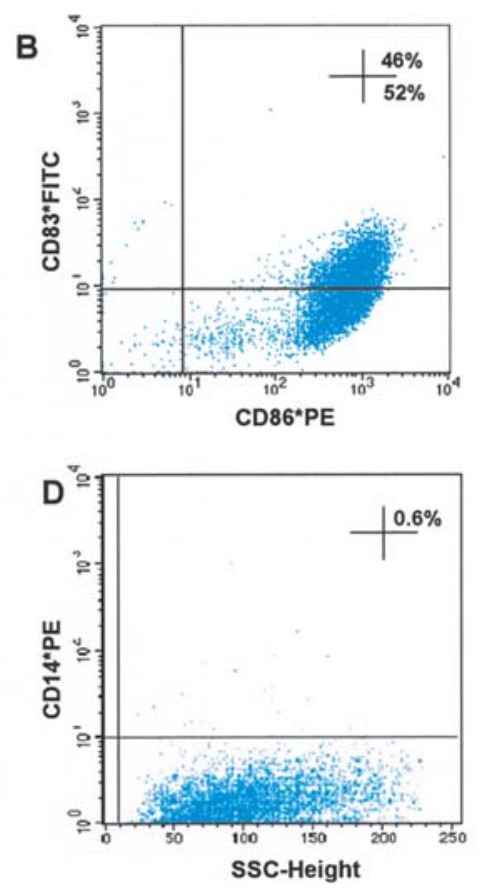

Figure 3. Phenotype of DCs generated from AML blasts. Representative results obtained by flow cytometric analysis of AML-DC vaccine preparations. Cells displayed a DC phenotype with high HLA-ABC expression (A), high expression of CD86 ${ }^{+}$with coexpression of CD83+ (B). Generated AML-DCs were clearly double-positive for HLA-DR ${ }^{+}$and $\mathrm{CD}_{4} 4^{+}(\mathrm{C})$, but did not express CD14 (D). For more details see Materials and methods, the percentage of positive cells is given in the respective panels, indicating the maturation of DCs from monocytic cells. 
A

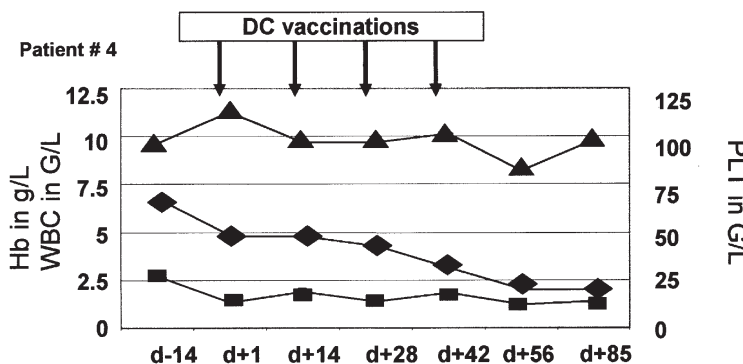

B

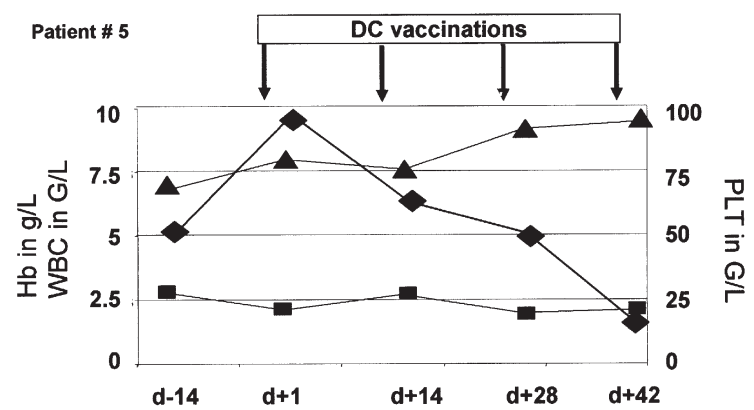

Figure 4. Clinical course of peripheral blood counts during AML-DC immunotherapy. Changes in the white blood cell (WBC) count in $\mathrm{G} / \mathrm{L}$ (closed squares), hemoglobin $(\mathrm{Hb})$ in $\mathrm{g} / \mathrm{L}$ (closed triangles) and platelet (PLT) counts in G/L (closed diamonds) during AML-DC treatment. Stable blood parameters values were observed in all patients. A, results from patient no. 4 ; and $\mathrm{B}$, from patient no. 5 .

A

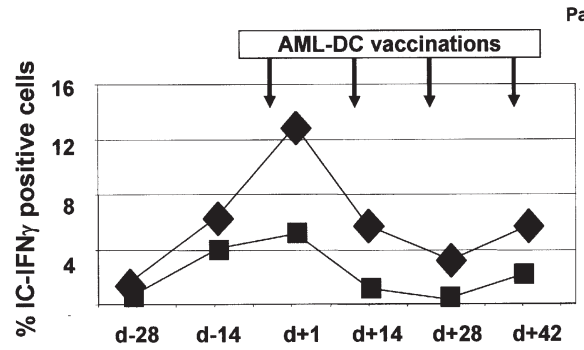

B

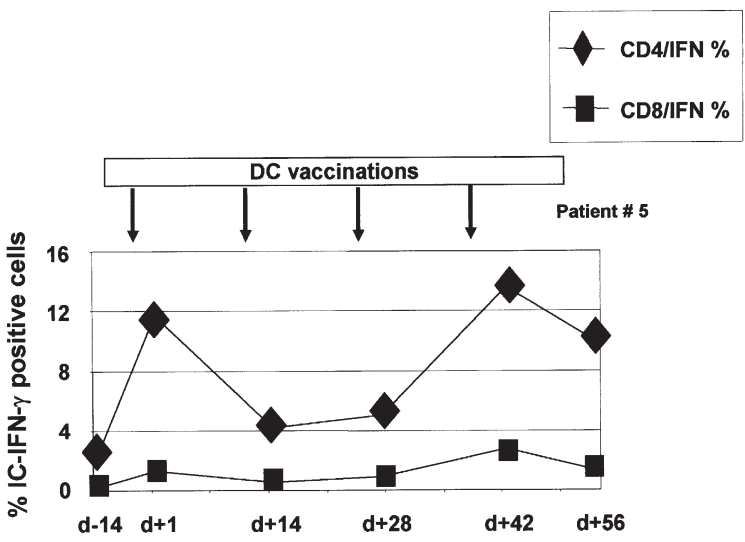

Figure 6. Changes in the intracellular IFN- $\gamma$ level of $\mathrm{CD}^{+}$and $\mathrm{CD} 8^{+}$cells during AML-DC vaccination. Percentages of intracellular IFN- $\gamma$ positive $\mathrm{CD}^{+}$(diamonds) and $\mathrm{CD}^{+}$(squares) at the indicated time-points in patient no. 4 (A) and patient no. 5 (B) as assessed by FACS analysis. While IFN- $\gamma$ levels in $\mathrm{CD}^{+} \mathrm{T}$ cells remained rather stable, an elevation of the IFN- $\gamma$ levels in $\mathrm{CD}^{+}{ }^{+} \mathrm{T}$ cells was observed.
A

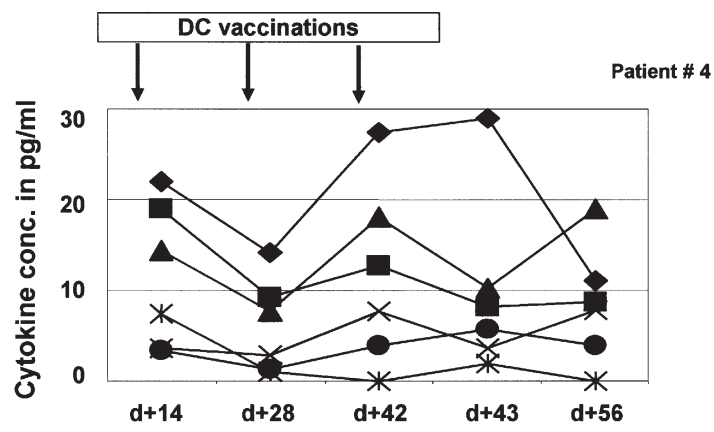

$\begin{array}{ll}\dashv \text { IFN } \gamma & \text { * IL-5 } \\ - \text { TNF a } & * \text { IL-4 } \\ \dashv \text { IL-10 } & \bullet-\text { IL-2 }\end{array}$

B

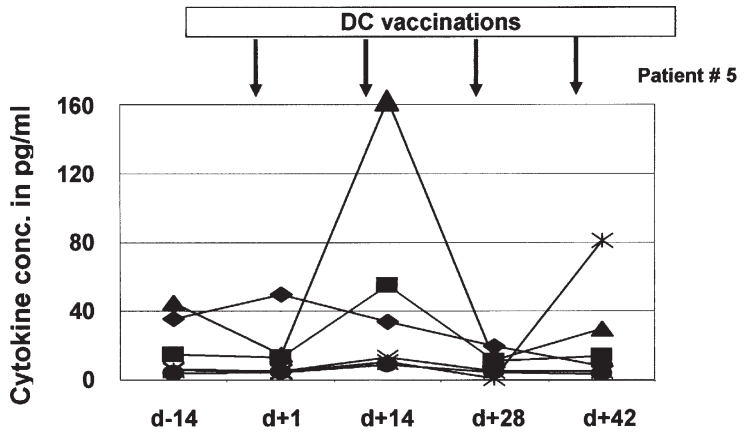

Figure 5. Changes in serum levels during AML-DC treatment as assessed by cytokine bead assay. Concentrations (pg/ml) of IFN- $\gamma$, TNF- $\alpha$, IL-10, IL-5, IL-4 and IL-2 in the serum of patient no. 4 (A) and patient no. 5 (B) during AML-DC vaccination.

cells generated from AML blasts (AML-DC) showed typical DC morphology with characteristic veils, an excentric nucleus and a diameter of $15-20 \mu \mathrm{m}$. A typical microphotograph of AML-DCs is shown in Fig. 2. AML-DC vaccine preparations were highly enriched with mature DCs. The mean viability of generated DCs was $93 \%(\mathrm{SD} \pm 6 \%$ ), the mean yield of viable DCs was $32 \times 10^{6}\left(\mathrm{SD} \pm 18 \times 10^{6}\right.$; minimum, $9.3 \times 10^{6}$; maximum, $87.2 \times 10^{6}$ ) cells. Fig. 3 shows a typical immunophenotype of DC generated from the AML patients by FACS analysis. The DC highly expressed CD54, CD83, CD86, HLA-DR and HLA-ABC; expression of CD14 was absent. AML-DC vaccines were checked for the existence of TAA detected before preparation on the AML blast to confirm the blast origin of AML-DC (data not shown).

Clinical responses. Three of five patients completed the treatment with four AML-DC vaccinations. One patient lived for 13 months after 4 vaccinations with a stable WBC count and without peripheral blasts but eventually died from pneumonia. Two patients received a single AML-DC vaccination and died thereafter due to intracranial hemorrhage. These serious adverse effects were most likely due to the progression of the underlying disease. Thrombocytopenia in these patients was preexisting. No anti-platelet antibodies could be detected or occurred after vaccination.

The fourth patient showed a drop of blasts from $8 \%$ to $0 \%$ in the peripheral blood over the period of AML-DC therapy. One month after four vaccinations, blasts reappeared (6\%). The 


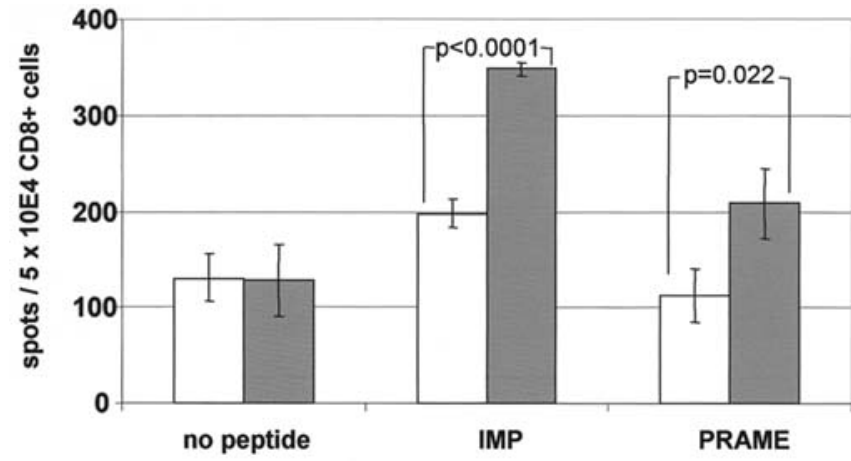

Figure 7. Activation of specific T lymphocytes after vaccination with AMLDCs. Enhanced specific CD8 ${ }^{+} \mathrm{T}$ cell responses against PRAME after vaccination with AML-DCs were assessed using an ELISPOT assay for granzyme B. Numbers stand for the mean value of spots per 50,000 CD8 ${ }^{+}$ cells in triplicate, error bars indicate the standard deviation. Before (white bars) and after four vaccinations (black bars), $\mathrm{CD}^{+} \mathrm{T}$ cells of the peripheral blood were evaluated for their specific secretion of granzyme B in ELISPOT assays against T2 cells pulsed with a PRAME-derived peptide, an influenza matrix protein (IMP)-derived peptide as a positive control or without peptide as a negative control. After vaccination with AML-DC, a significant increase of $\mathrm{CD}^{+} \mathrm{T}$ cells recognizing the PRAME-peptide was observed, indicating an enhancement of the anti-leukemic $\mathrm{T}$ cell response. P-values were calculated using the unpaired t-test.

disease progressed and the patient died from sepsis 6 months after his first AML-DC vaccination. The fifth patient developed a stable WBC count during immunotherapy. After the last vaccination, the peripheral leukemic blast count initially dropped from $20 \%$ to $0 \%$. However, one month after the last AML-DC vaccination, blasts reappeared in the $\mathrm{PB}$ of this patient. Low dose Ara-C (2x20 mg s.c.) was started as palliative treatment but, 5.5 months after his first AML-DC vaccination, the patient died in the phase of aplasia due to gastrointestinal hemorrhage. During immunotherapy, a stable WBC count was observed (Fig. 4).

Toxicity. All vaccinations were well tolerated and no severe side effects were associated with the s.c. injections of AML-DCs. Patients developed a mild local reaction (erythema, induration, pruritus) at the vaccination site which, in all cases, resolved within a few days. Renal function and liver function were not impaired. No signs of autoimmunity were detected as measured by rheumatoid factor, C-reactive protein and anti-nuclear antibodies.

Immunological response and Th1/Th2 response. The levels of IL-2, IL-4, IL-5, IL-10, TNF- $\alpha$ and IFN- $\gamma$ were measured by FACS analysis as described in Materials and methods. For patients 4 and 5, we observed a wide fluctuation of Th1/Th2 cytokine secretion during the AML-DC based immunotherapy (Fig. 5). To specify the IFN- $\gamma$ secreting cells, intracellular FACS staining was performed. After vaccination, intracellular levels of IFN- $\gamma$ in CD4 were 2- to 4-fold higher than before treatment (Fig. 6). Interestingly, after the 4th vaccination, an increase of IFN- $\gamma$ in patient no. 4 was noticed and, in patient no. 5 , there was a peak of IL-4 which correlated with a drop of blasts in the PB. In patient no. 5, an 8-fold increase of IL-10 and a 4-fold elevation of TNF- $\alpha$ was observed in the serum.
Specific cellular immune responses. To demonstrate a leukemiaspecific $\mathrm{T}$ cell immune response, ELISPOT assays for $\mathrm{CD}^{+}$ $\mathrm{T}$ lymphocytes specifically reactive against the antigen, PRAME, were performed, a TAA which is expressed on AML-blasts, but not on cells of the nomal hematopoiesis. T cell reactivity to an influenza matrix protein peptide served as a positive control, an assay against unloaded CD8 negative antigen presenting cells as a negative control. The assays clearly demonstrate a general increase of $\mathrm{T}$ cell activation as measured by IMP specific $\mathrm{T}$ cells, but also a significant $(\mathrm{p}=0.022)$ increase of anti-leukemic $\mathrm{T}$ cell response as measured by PRAME specific $\mathrm{T}$ cell frequencies.

ELISPOT measuring the release of granzyme B was used to detect the reactivity of PRAME derived peptide presensitized $\mathrm{CD}^{+} \mathrm{T}$ cells before and after vaccination. After vaccination, an increased granzyme B secretion by $\mathrm{T}$ cell reacting against $\mathrm{T} 2$ target cells pulsed with a PRAME epitope peptide was observed (Fig. 7).

\section{Discussion}

The donor lymphocyte infusion (DLI) and graft versus leukemia (GVL) effects suggest the existence of immunogenic tumor associated antigens in AML patients (18). Several clinical TAA peptide vaccination trials for AML patients have entered phase I/II studies, including the RHAMM/ CD168 peptide R3 vaccination trial initiated at our institution. After vaccination with a Wilms tumor gene 1 (WT-1) peptide, encouraging results and even complete remissions were observed in AML patients $(19,20)$.

We demonstrated previously that DCs generated from leukemic blasts express costimulatory molecules (CD40, CD80, CD86), HLA class I and II molecules, and TAA, thus indicating the potential of AML blasts to act as immune targets $(9,21)$. Several other groups have detected the potency of DC derived from blasts to induce specific immune responses against TAA in vitro $(7-9,12-15)$. Moreover, vaccination with irradiated AML cells transfected with B7.1 or GM-CSF was efficient in vivo to reject established leukemia in a murine AML model (22).

The general safety of DC vaccination has been proven in clinical trials for patients with several tumor entities, such as B-cell lymphoma, renal cell carcinoma, melanoma and prostate cancer (23-28). In AML patients, DCs pulsed with tumor lysates were shown to be safe and effective in eliciting an immunological response but no clinical benefit was demonstrated (29).

In the present study, we demonstrate that clinical vaccination is feasible and safe in patients with AML. Three of our five patients who completed a course of vaccination were subjected to functional $\mathrm{T}$ cell assays. In one patient, results obtained by ELISPOT assay indicate an increased granzyme B production to target $\mathrm{T} 2$ cells pulsed with a PRAME derived peptide. The lysis of tumor cells by activated IFN- $\gamma$ producing $\mathrm{T}$ lymphocytes through granzyme B plays a main role in tumor rejection (30). In two other patients, the intracellular IFN- $\gamma$ production increased during and after the DC vaccination and could be assigned to $\mathrm{CD} 4^{+}$cells rather than $\mathrm{CD} 8^{+} \mathrm{T}$ cells with higher levels of IFN- $\gamma$ production in $\mathrm{CD}^{+}{ }^{+}$cells. Activation of $\mathrm{CD}^{+}$cells plays an important role in anti-tumor immunity, 
as $\mathrm{CD}^{+}{ }^{+} \mathrm{T}$ helper cells are able to provide regulatory signals required for the priming of $\mathrm{MHC}$ I restricted $\mathrm{CD}^{+} \mathrm{T}$ cells, which are crucial effector cells in tumor rejection (31). Our data underline the importance of $\mathrm{CD}^{+} \mathrm{T}$ cells in the antileukemic action of the immune system.

The cytokine response shows fluctuations during therapy with some interesting findings; both types of cytokines Th1 and Th2 were noted in elevated levels and, in patient no. 5, Th1 response was revealed to be more pronounced. In patient no. 4 , the increased IFN- $\gamma$ production was maintained for one day after vaccination (Fig. 5). Interestingly, the boost of IL-4 correlated with a drop of blasts in the peripheral blood of patient no. 5 (Fig. 5B).

In this study, we demonstrated immunological responses in AML patients treated with AML-DC vaccine. An increased specific CTL response against TAA PRAME was observed after four vaccinations.

Our clinical approach of vaccination with autologous AML-DCs is neither restricted to any HLA type nor limited to any particular TAA expressed on leukemic blasts since most of the evaluable TAA/LAA are maintained or even upregulated during DC generation, as we have reported previously $(8,9)$. AML-DC developed the potential to activate both $\mathrm{CD}^{+}$and $\mathrm{CD}^{+}$cells and to induce both Th1 and Th2 responses. We also recently described the expression of tolllike receptors on AML blasts as prerequisite for $\mathrm{CpG}$ action (Li L, et al, Blood, ASH abs. no. 1812, 104, 2004). Therefore, as a future perspective, AML patients might benefit from AML-DC vaccinations enhanced by powerful adjuvants such as keyhole limpet hemocyanin (KLH) or CG rich oligonucleotides (CpG-ODNs) (32).

\section{Acknowledgements}

We would like to thank Ms. Marlies Götz and Ms. Brigit Maccari for their excellent technical support in this study.

\section{References}

1. Stone RM, O'Donnell MR and Sekeres MA: Acute myeloid leukemia. (ASH Educ Program). Hematology: 98-117, 2004.

2. Banchereau J, Brière F, Caux C, Davoust J, Lebecque S, Liu YJ and Palucka K: Immunobiology of dendritic cells. Annu Rev Immunol 18: 767-811, 2000

3. Banchereau J, Schuler-Thurner B, Palucka AK and Schuler G: Dendritic cells as vectors for therapy. Cell 106: 271-274, 2001.

4. Hus I, Rolinski J, Tabarkiewicz J, Wojas K, Bojarska-Junak A, Greiner J, Giannopoulos K, Dmoszynska A and Schmitt M: Allogeneic dendritic cells pulsed with tumor lysates or apoptotic bodies as immunotherapy for patients with early stage B-cell chronic lymphocytic leukemia (B-CLL). Leukemia (In press).

5. Cignetti A, Bryant E, Allione B, Vitale A, Foa R and Cheever MA: $\mathrm{CD} 34^{+}$acute myeloid and lymphoid leukemic blasts can be induced to differentiate into dendritic cells. Blood 94: 2048-2055, 1999.

6. Kohler T, Plettig R, Wetzstein W, Schmitz M, Ritter M, Mohr B, Schaekel U, Ehninger G and Bornhäuser M: Cytokine-driven differentiation of blasts from patients with acute myelogenous and lymphoblastic leukemia into dendritic cells. Stem Cells 18: 139-147, 2000

7. Choudhury A, Liang JC, Thomas EK, Flores-Romo L, Xie QS, Agusala K, Sutaria S, Sinha I, Champlin RE and Claxton DF: Dendritic cells derived in vitro from acute myelogenous leukemia cells stimulate autologous antileukemic T cell responses. Blood 93: 780-786, 1999 .
8. Li L, Reinhardt P, Schmitt A, Barth TF, Greiner J, Ringhoffer M, Döhner H, Wiesneth M and Schmitt M: Dendritic cells generated from acute myeloid leukemia (AML) blasts maintain the expression of immunogenic leukemia associated antigens. Cancer Immunol Immunother 54: 685-693, 2005.

9. Li L, Schmitt A, Reinhardt P, Greiner J, Ringhoffer M, Vaida B, Bommer M, Vollmer M, Wiesneth M, Döhner H and Schmitt M: Reconstitution of CD40 and CD80 in dendritic cells generated from blasts of patients with acute myeloid leukemia. Cancer Immun 3: 8, 2003.

10. Ikeda H, Lethe B, Lehmann F, van Baren N, Baurain JF, De Smet C, Chambost H, Vitale M, Moretta A, Boon T and Coulie PG: Characterization of an antigen that is recognized on a melanoma showing partial HLA loss by CTL expressing an NK inhibitory receptor. Immunity 6: 199-208, 1997.

11. Oka Y, Udaka K, Tsuboi A, Elisseeva OA, Ogawa H, Aozasa K, Kishimoto $\mathrm{T}$ and Sugiyama H: Cancer immunotherapy targeting Wilms' tumor gene WT1 product. J Immunol 164: 1873-1880, 2000.

12. Charbonnier A, Gaugler B, Sainty D, Lafage-Pochitaloff M and Olive D: Human acute myeloblastic leukemia cells differentiate in vitro into mature dendritic cells and induce the differentiation of cytotoxic T cells against autologous leukemias. Eur J Immunol 29: 2567-2578, 1999 .

13. Stripecke R, Levine AM, Pullarkat V and Cardoso AA: Immunotherapy with acute leukemia cells modified into antigen-presenting cells: ex vivo culture and gene transfer methods. Leukemia 16: 1974-1983, 2002

14. Woiciechowsky A, Regn S, Kolb H-I and Roskrow M: Leukemic dendritic cells generated in the presence of FLT3 ligand have the capacity to stimulate an autologous leukemia-specific cytotoxic T cell response from patients with acute myeloid leukemia. Leukemia 15: 246-255, 2001

15. Kufner S, Fleischer RP, Kroell T, Schmid C, Zitzelsberger H, Salih H, Valle FD, Treder W and Schmetzer HM: Serum-free generation and quantification of functionally active leukemiaderived DC is possible from malignant blasts in acute myeloid leukemia and myelodysplastic syndromes. Cancer Immunol Immunother, 2005 E-pub ahead of print.

16. Klammer M, Waterfall M, Samuel K, Turner ML and Roddie PH: Fusion hybrids of dendritic cells and autologous myeloid blasts as a potential cellular vaccine for acute myeloid leukaemia. Br J Haematol 129: 340-349, 2005.

17. Greiner J, Li L, Ringhoffer M, Barth TF, Giannopoulos K, Guillaume P, Ritter G, Wiesneth M, Döhner H and Schmitt M: Identification and characterization of epitopes of the receptor for hyaluronic acid mediated motility (RHAMM/CD168) recognized by CD8 positive T cells of HLA-A2 positive patients with acute myeloid leukemia. Blood 106: 938-945, 2005.

18. Margolis J, Borrello I and Flinn IW: New approaches to treating malignancies with stem cell transplantation. Semin Oncol 27: 524-530, 2000.

19. Mailander V, Scheibenbogen C, Thiel E, Letsch A, Blau IW and Keilholz U: Complete remission in a patient with recurrent acute myeloid leukemia induced by vaccination with WT1 peptide in the absence of hematological or renal toxicity. Leukemia 18: 165-166, 2004.

20. Oka Y, Tsuboi A, Taguchi T, Osaki T, Kyo T, Nakajima H, Elisseeva OA, Oji Y, Kawakami M, Ikegame K, Hosen N, Yoshihara S, Wu F, Fujiki F, Murakami M, Masuda T, Nishida S, Shirakata T, Nakatsuka S, Sasaki A, Udaka K, Dohy H, Aozasa K, Noguchi S, Kawase I and Sugiyama H: Induction of WT1 (Wilms' tumor gene)-specific cytotoxic T lymphocytes by WT1 peptide vaccine and the resultant cancer regression. Proc Natl Acad Sci USA 101: 13885-13890, 2004.

21. Vollmer M, Li L, Schmitt A, Greiner J, Reinhardt P, Ringhoffer M, Wiesneth M, Döhner H and Schmitt M: Expression of human leucocyte antigens and co-stimulatory molecules on blasts of patients with acute myeloid leukaemia. Br J Haematol 120: 1000-1008, 2003.

22. Dunussi-Joannopoulos K, Weinstein HJ, Arceci RJ and Croop JM: Gene therapy with B7.1 and GM-CSF vaccines in a murine AML model. J Pediatr Hematol Oncol 19: 536-540, 1997.

23. Hsu FJ, Benike C, Fagnoti F, Liles TM, Czerwinski D, Taidi B, Engelman EG and Levy R: Vaccination of patients with B-cell lymphoma using autologous antigen-pulsed dendritic cells. Nat Med 2: 52-58, 1996. 
24. Trefzer U, Weingart G, Chen Y, Herberth G, Adrian K, Winter H, Audring H, Guo Y, Sterry W and Walden P: Hybrid cell vaccination for cancer immune therapy: first clinical trial with metastatic melanoma. Int J Cancer 85: 618-626, 2000.

25. Su Z, Dannull J, Heiser A, Yansey D, Pruitt S, Madden J, Coleman D, Niedzwicki D, Gilboa E and Vieweg J: Immunological and clinical responses in metastatic renal cancer patients with tumor-RNA-transfected dendritic cells. Cancer Res 63: 2127-2133, 2003

26. Nishiyama T, Tachibana M, Horiguchi Y, Nakamura K, Ikeda Y, Takesako $\mathrm{K}$ and Murai M: Immunotherapy of bladder cancer using autologous dendritic cells pulsed with human lymphocyte antigen-A24-specific MAGE-3 peptide. Clin Cancer Res 7: 23-31, 2001.

27. Rasmussen T, Hansson L, Osterborg A, Johnsen HE and Mellstedt H: Idiotype vaccination in multiple myeloma induced a reduction of circulating clonal tumor $\mathrm{B}$ cells. Blood 101: 4607-4610, 2003.
28. Ruffini PA, Neelapu SS, Kwak L and Biragyn A: Idiotypic vaccination for $\mathrm{B}$-cell malignancies as a model for therapeutic cancer vaccines: from prototype protein to second generation vaccines. Haematologica 87: 989-1001, 2002.

29. Lee JJ, Kook H, Park MS, Nam JH, Choi BH, Song WH, Park KS, Lee IK, Chung IJ, Hwang TJ and Kim HJ: Immunotherapy using autologous monocyte-derived dendritic cells pulsed with leukemic cell lysates for acute myeloid leukemia relapse after autologous peripheral blood stem cell transplantation. J Clin Apheresis 19: 66-70, 2004.

30. Russell JH and Ley TJ: Lymphocyte-mediated cytotoxicity. Annu Rev Immunol 20: 323-370, 2002.

31. Hung K, Hayashi R, Lafond-Walker A, Lowenstein C, Pardoll D and Levitsky H: The central role of CD4 (+) T cells in the antitumor immune response. J Exp Med 188: 2357-2368, 1998.

32. Klinman DM, Currie D, Gursel I and Verthelyi D: Use of CpG oligodeoxynucleotides as immune adjuvants. Immunol Rev 199: 201-216, 2004. 